\title{
COLLABORATIVE INFRASTRUCTURES FOR MOBILIZING INTELLECTUAL RESOURCES: \\ ASSESSING INTELLECTUAL BANDWIDTH IN A KNOWLEDGE INTENSIVE ORGANIZATION
}

\author{
R. Verhoef and S. Qureshi
}

\begin{tabular}{|l|l|}
\hline \multicolumn{2}{|l|}{ ERIM REPORT SERIES RESEARCH IN MANAGEMENT } \\
\hline ERIM Report Series reference number & ERS-2004-060-LIS \\
\hline Publication & June 2004 \\
\hline Number of pages & 19 \\
\hline Email address corresponding author & squreshi@mail.unomaha.edu \\
\hline Address & Erasmus Research Institute of Management (ERIM) \\
& Rotterdam School of Management / Rotterdam School of \\
& Economics \\
& Erasmus Universiteit Rotterdam \\
& P.O. Box 1738 \\
& 3000 DR Rotterdam, The Netherlands \\
& Phone: +31 10 408 1182 \\
& Fax: +31 10 408 9640 \\
& Email: info@erim.eur.nl \\
& Internet: www.erim.eur.nl \\
\hline
\end{tabular}

Bibliographic data and classifications of all the ERIM reports are also available on the ERIM website: www.erim.eur.nl 


\title{
ERASMUS RESEARCH INSTITUTE OF MANAGEMENT
}

\author{
REPORT SERIES \\ RESEARCH IN MANAGEMENT
}

\begin{tabular}{|c|c|c|}
\hline \multicolumn{3}{|c|}{ BIBLIOGRAPHIC DATA AND CLASSIFICATIONS } \\
\hline Abstract & \multicolumn{2}{|c|}{$\begin{array}{l}\text { The use of intellectual assets of key professionals to provide customized goods and services is } \\
\text { seen to be a key characteristic of knowledge intensive organizations. While knowledge } \\
\text { management efforts have become popular in organizations that depend on the knowledge and } \\
\text { skills of their employees, it is unclear what the benefits of such efforts are and how these } \\
\text { intellectual resources may actually create value for the organization. At the same time, vast } \\
\text { information and communication technology infrastructures are being implemented to tap into the } \\
\text { diverse intellectual resources to little effect. This paper uses the Intellectual Bandwidth Model } \\
\text { originally developed by Nunamaker et al. (2001) to investigate the extent to which do } \\
\text { collaborative technologies support the mobilization of intellectual resources to create value for an } \\
\text { organization. Following a investigation of the intellectual bandwidth of a large multinational } \\
\text { consulting company, this paper provides insight into the role of technology for mobilizing } \\
\text { intellectual resources and offers implications for developing infrastructure to support core } \\
\text { business processes. }\end{array}$} \\
\hline \multirow{3}{*}{$\begin{array}{l}\text { Library of Congress } \\
\text { Classification } \\
\text { (LCC) }\end{array}$} & $5001-6182$ & Business \\
\hline & $5201-5982$ & Business Science \\
\hline & HD 30.3 & Communication of Information \\
\hline \multirow{4}{*}{$\begin{array}{l}\text { Journal of Economic } \\
\text { Literature } \\
\text { (JEL) }\end{array}$} & M & Business Administration and Business Economics \\
\hline & M 11 & Production Management \\
\hline & R 4 & Transportation Systems \\
\hline & L 15 & Information \\
\hline \multirow{4}{*}{$\begin{array}{l}\text { European Business Schools } \\
\text { Library Group } \\
\text { (EBSLG) }\end{array}$} & $85 \mathrm{~A}$ & Business General \\
\hline & $260 \mathrm{~K}$ & Logistics \\
\hline & $240 \mathrm{~B}$ & Information Systems Management \\
\hline & $78 \mathrm{~B}$ & Organizational Psychology, perception \\
\hline \multicolumn{3}{|c|}{ Gemeenschappelijke Onderwerpsontsluiting (GOO) } \\
\hline \multirow[t]{4}{*}{ Classification GOO } & 85.00 & Bedrijfskunde, Organisatiekunde: algemeen \\
\hline & 85.34 & Logistiek management \\
\hline & 85.20 & Bestuurlijke informatie, informatieverzorging \\
\hline & 85.20 & Bestuurlijke informatie, informatieverzorging \\
\hline \multirow[t]{3}{*}{ Keywords GOO } & \multicolumn{2}{|c|}{ Bedrijfskunde / Bedrijfseconomie } \\
\hline & \multicolumn{2}{|c|}{ Bedrijfsprocessen, logistiek, management informatiesystemen } \\
\hline & \multicolumn{2}{|c|}{ Kennisoverdracht, samenwerking, ICT, kennismanagement, virtuele organisatie } \\
\hline Free keywords & \multicolumn{2}{|c|}{ Intellectual Bandwidth (IB), Electronic Collaboration, Uniderstanding, Interdependence of Efforts } \\
\hline
\end{tabular}




\title{
Collaborative Infrastructures for Mobilizing Intellectual Resources: Assessing Intellectual Bandwidth in a Knowledge Intensive Organization.
}

\author{
Rick Verhoef \\ Proven Partners BV \\ Knowledge Management Services in Practice \\ Zürichtoren, Muzenstraat 89 \\ 2511 WB, Den Haag \\ Phone: +31.6.5182.4989 \\ E-mail: rick@provenpartners.nl
}

\author{
Sajda Qureshi \\ Department of Information Systems \& Quantitative Analysis, \\ College of Information Science \& Technology \\ University of Nebraska at Omaha \\ 6001 Dodge Street, Omaha, NE 68182-0116 \\ Phone: +1.402.554.2837, fax: +1.402.554.3400 \\ And \\ Rotterdam School of Management \\ Erasmus University Rotterdam \\ E-mail: squreshi@mail.unomaha.edu
}

\begin{abstract}
The use of intellectual assets of key professionals to provide customized goods and services is seen to be a key characteristic of knowledge intensive organizations. While knowledge management efforts have become popular in organizations that depend on the knowledge and skills of their employees, it is unclear what the benefits of such efforts are and how these intellectual resources may actually create value for the organization. At the same time, vast information and communication technology infrastructures are being implemented to tap into the diverse intellectual resources to little effect. This paper uses the Intellectual Bandwidth Model originally developed by Nunamaker et al. (2001) to investigate the extent to which do collaborative technologies support the mobilization of intellectual resources to create value for an organization. Following a investigation of the intellectual bandwidth of a large multinational consulting company, this paper provides insight into the role of technology for mobilizing intellectual resources and offers implications for developing infrastructure to support core business processes.
\end{abstract}

\section{Introduction}

Intellectual assets are increasingly being seen as strategic resources that need to be created and harnessed effectively in order for organizations to survive and achieve competitive advantage. It is believed that managing this strategic resource can enable 
an organization to achieve particular benefits such as minimization of costs, innovation of products, product development procedures, improved quality, flexibility in a dynamic market and improved customer service. Knowledge must also be useful and it must have strategic value (Zack, 1999). This means that it should impact organizational strategic objectives that add most value such as customer service, market leadership or operational effectiveness. In this context, the term "intellectual capital" (or intellectual assets) is often used to represent knowledge that can be converted into profit and create value or the sum of everything everybody in a company knows that gives it a competitive edge (Stewart, 1997).

The effective performance and growth of knowledge intensive organizations requires integrating and sharing knowledge that is often highly distributed (Zack, 1999). Distributed knowledge is often personalized and resides in pockets and communities within and outside of the organization. It has been suggested that problems which stem from traditional business environments that hoard knowledge are an obstacle which is preventing knowledge management efforts from being a complete success (Hibbard and Carrillo, 1998). In addition, Vance (1997) suggests that the reason information and knowledge may not be easily transferred from the holder to the person needing it may be because it is inarticulable in the mind of the holder.

In recent years, Information and communication technology (ICT) are seen to have become a key resource that if used effectively can enable dispersed knowledge to be used for developing innovative and customized goods and services. Technologies that support the creation and management of knowledge are seen to fall into a pre-defined set of activities. These activities relate to processes defined by Huber (1991) to be knowledge acquisition and assimilation, dissemination and sharing, and utilization. Alavi and Leidner (1999) identify an emerging line of information systems referred to as Knowledge Management Systems (KMS) that target professional and managerial activities by focusing on creating, gathering, organizing and disseminating an organization's "knowledge" as opposed to "information" or "data". In addition, Hibbard and Carrillo (1998) believe the information technology that supports knowledge management, such as data mining, groupware, document management and search and retrieval, are widely available and already exist in many companies. Organizational 
memory information systems have been important to organizations as it is recognized that knowledge is a key component to competitiveness (Stein and Zwass, 1995).

However, these traditional tools for knowledge management are often not suited for enabling dispersed knowledge to be used for the production and delivery of customized and innovative goods and services. This is because Knowledge Management efforts in organizations concentrate on codifying or explicating tacit knowledge and propose infrastructures for storing explicit knowledge as well as refining, managing and distributing it (Zack, 1999 and Hansen et al., 1999). In addition, knowledge management is seen to be the remit of departments or units that act separate from the main focus of the organization. This means that while such efforts may have priority, it is not clear what the deliverables or value to the organization may be.

This paper focuses on the use of technologies to support the mobilization of an organization's intellectual resources. Nunamaker et al. (2001) and Qureshi et al. (2002) suggest that an organization's potential to create value through the use of its intellectual capital is affected by the extent to which collaborative activities can take place. This is especially true since Tallon et al. (2000) suggest that there are critical business activities within a firm's value system that effect its ability to create value. These include aspects of production, logistics, sales, marketing, customer service, and administrative support often illustrated within the context of a value chain. Technologies that enable dispersed and local knowledge to be used for these critical business activities have collaborative components and link different locations. This type of infrastructure has become a powerful means of capturing, exchanging, and managing personalized organizational knowledge. In this way, electronic collaboration becomes instrumental in capitalizing on an organization's intellectual capital.

The key question investigated in this paper is to what extent do collaborative technologies support the mobilization of intellectual resources to create value for an organization? An investigation is carried out on the collaborative technologies used by a large multinational consulting company which we term BIG4 to protect its privacy. The Intellectual Bandwidth model originally developed by Nunamaker et al. (2001) is used to investigate the potential of this organization to create value through its intellectual resources. BIG4's technology infrastructure developed for managing knowledge is 
evaluated using the Intellectual Bandwidth model. Following an analysis of BIG4's intellectual bandwidth, this paper provides insight into the role of technology for mobilizing intellectual resources and offers implications for developing infrastructure to support core business processes.

\section{The Intellectual Bandwidth Model}

An organization's Intellectual Bandwidth is its ability to mobilize intellectual assets to create value and is its ability to bring its intellectual capital to bear on the tasks at hand (Nunamaker et al., 2001a, 2001b, 2002 and Qureshi et al., 2002). Qureshi and Briggs (2003) suggest that value is important because if an organization that seeks to create value for its stakeholders, must be able to bring its intellectual capital (IC) to bear on its tasks. An organization's intellectual capital is embodied in its repeatable processes, in the understandings of its members, and in its physical repositories of knowledge (Nunamaker et al., 2001a). It seems that the higher is an organization's intellectual bandwidth, the higher would be its potential to create value. In order to create value organizations could aim to maximize their intellectual bandwidth. By leveraging the creation and use of their intellectual assets organizations can maximize their intellectual bandwidth.

The intellectual bandwidth model suggests that understanding consists of data, information, knowledge and wisdom. Many authors refer to data as raw facts or simple observations about the state of the world; information is data in some context or with some kind of human interpretation applied; and knowledge is information with guidance for action, that is: knowing how to act given the information (Davenport, 1997 and Tuomi, 2000 and Courtney, 2001 and Sowell, 1980). This is consistent with the definitions used by Nunamaker et al. (2002) who add wisdom to the hierarchy of understanding. Qureshi and Briggs (2003) contribute to this hierarchy of understanding by suggesting that data is the understanding of symbols, information is understanding the relationships among symbols in the context in which they are presented, knowledge is understanding the patterns in the context from which they emerge and Wisdom is Understanding Principles or causes and consequences inferred by recognizing useful principles that emerge as one considers patterns within knowledge. Figure 1 illustrates the Intellectual Bandwidth Model. 


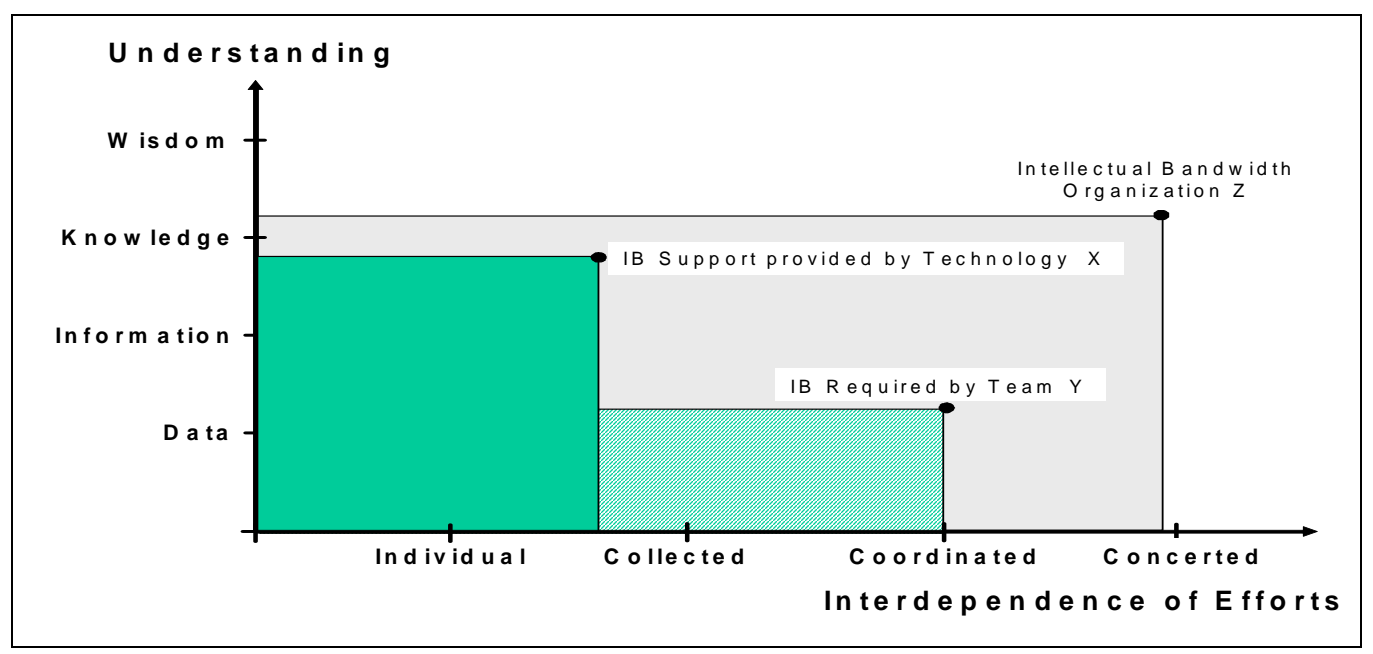

Figure 1: Revised Model of Intellectual Bandwidth, Qureshi and Briggs (2003) The vertical axis represents a hierarchy of understanding. The horizontal axis represents a continuum of the interdependence of efforts required for a team to succeed.

The continuum of interdependence is the degree to which the efforts of team members must be interdependent in order for the team to succeed (Qureshi and Briggs, 2003). It consists of the Individual Work Mode in which people work independently of others, the Collective Work Mode in which team work involves the simple sum of individual work, Coordinated Work Mode involves managing sequential interdependencies between individual activities and Concerted Work Mode which all members work in concert to produce a joint deliverable. In order to measure the Intellectual Bandwidth (IB) of an organization, the hierarchy of understanding and continuum of interdependencies described above need to be assessed. The following table illustrates the key concepts used to collect data on the IB constructs: 


\begin{tabular}{|c|c|c|c|c|}
\hline Understanding & \multicolumn{4}{|c|}{ Intellectual Bandwidth } \\
\hline Wisdom & $\begin{array}{l}\text { Independent } \\
\text { understanding of } \\
\text { principles or } \\
\text { causes and } \\
\text { consequences } \\
\text { that emerge }\end{array}$ & $\begin{array}{l}\text { Sum of multiple } \\
\text { understanding of } \\
\text { principles or } \\
\text { causes and } \\
\text { consequences } \\
\text { that emerge }\end{array}$ & $\begin{array}{l}\text { Manage } \\
\text { interdependen- } \\
\text { cies between } \\
\text { different } \\
\text { understandings of } \\
\text { principles or } \\
\text { causes and } \\
\text { consequences } \\
\text { that emerge }\end{array}$ & $\begin{array}{l}\text { Joint deliverable } \\
\text { based upon } \\
\text { synchronized } \\
\text { understandings of } \\
\text { principles or } \\
\text { causes and } \\
\text { consequences } \\
\text { that emerge }\end{array}$ \\
\hline Knowledge & $\begin{array}{l}\text { Independent } \\
\text { understanding of } \\
\text { patterns in context } \\
\text { of their } \\
\text { emergence. } \\
\text { Knowing how to } \\
\text { act given the } \\
\text { information }\end{array}$ & $\begin{array}{l}\text { Simple sum of } \\
\text { multiple } \\
\text { understandings of } \\
\text { patterns in context } \\
\text { of their } \\
\text { emergence. } \\
\text { Collectively } \\
\text { knowing how to } \\
\text { act given the } \\
\text { information }\end{array}$ & $\begin{array}{l}\text { Manage } \\
\text { interdependen- } \\
\text { cies between } \\
\text { different } \\
\text { understandings of } \\
\text { patterns in context } \\
\text { of their } \\
\text { emergence. } \\
\text { Coordinating } \\
\text { action given the } \\
\text { information }\end{array}$ & $\begin{array}{l}\text { Joint deliverable } \\
\text { based upon } \\
\text { synchronized } \\
\text { understandings of } \\
\text { patterns in context } \\
\text { of their } \\
\text { emergence. } \\
\text { Concerted action } \\
\text { given the } \\
\text { information }\end{array}$ \\
\hline Information & $\begin{array}{l}\text { Independent } \\
\text { interpretation of } \\
\text { facts and simple } \\
\text { observations }\end{array}$ & $\begin{array}{l}\text { Simple sum of } \\
\text { multiple } \\
\text { interpretations of } \\
\text { facts and simple } \\
\text { observations }\end{array}$ & $\begin{array}{l}\text { Manage } \\
\text { interdependen- } \\
\text { cies between } \\
\text { different } \\
\text { interpretations of } \\
\text { facts and simple } \\
\text { observations }\end{array}$ & $\begin{array}{l}\text { Joint deliverable } \\
\text { based upon } \\
\text { synchronized } \\
\text { interpretations of } \\
\text { facts and simple } \\
\text { observations }\end{array}$ \\
\hline Data & $\begin{array}{l}\text { Independent } \\
\text { recording of facts } \\
\text { and simple } \\
\text { observations }\end{array}$ & $\begin{array}{l}\text { Simple sum of } \\
\text { records of facts } \\
\text { and simple } \\
\text { observations }\end{array}$ & $\begin{array}{l}\text { Manage } \\
\text { interdependen- } \\
\text { cies between } \\
\text { different records } \\
\text { of facts and } \\
\text { simple } \\
\text { observations }\end{array}$ & $\begin{array}{l}\text { Joint deliverable } \\
\text { based upon } \\
\text { synchronized } \\
\text { recording of facts } \\
\text { and simple } \\
\text { observations }\end{array}$ \\
\hline $\begin{array}{l}\text { Interdependenci } \\
\text { es }\end{array}$ & Individual & Collected & Coordinated & Concerted \\
\hline
\end{tabular}

Technologies for collaboration appear to enable the sharing and use of distributed knowledge within virtual organizations. Developments in collaborative technology are increasingly focusing on multi-location technology. This means that instead of bringing groups together in an electronic meeting room, the electronic meeting facility can move to places where groups can meet - cyberspace. For optimum collaborative knowledge management activities, organizations must seek collaborative support that extends the electronic meeting room into an electronic meeting space, enabling any time any place collaboration. According to Courtney et al. (1998) a good telecommunications network which supports electronic and voice mail, groupware, integrated databases, multimedia presentations, graphical user interfaces, and client server architectures can greatly enhance the ease with which knowledge can be acquired, shared, compared and used. 
The following section assesses the extent to which collaboration technologies enable intellectual bandwidth to be utilized.

\section{Methodology}

A case study method was used to research the intellectual bandwidth of BIG4. The empirical research that examines intellectual bandwidth within its real context, particularly when the borders between phenomenon and context are not clear (Yin, 1994). Concepts within the hierarchy of understanding and continuum of interdependencies were measured through questionnaires on a five point scale, and observations, informal conversation and open-ended interviews. Assessing the intellectual bandwidth in an organization that relies on collaboration technologies to manage its intellectual assets needs to consider technology use in more detail. The technology infrastructure was evaluated using a survey which was administered to 503 professionals within BIG4. These professionals belonged to all different units working mainly for one of the lines of business that BIG4 serves. 121 responses were obtained from BIG4's professionals involved in the line of business named "Public Services Sector". After the survey 8 interviews were held with key persons within the organization to deepen the most striking results of the survey. These key persons were consultants, managers and a partner.

\section{Research Setting: Case Study of BIG4}

The case chosen to investigate electronic knowledge mobilization is the Dutch branch firm of a global assurance and advisory services firm. In order to protect its privacy, in this paper we call this company BIG4 Netherlands. We also renamed the name specific units and technologies used within the company. BIG4 Netherlands is part of the global BIG4 organization. More than 100.000 employees in 155 countries are operative worldwide at 760 offices. In the Netherlands about 4400 people work at the Dutch BIG4 branch in 23 offices. The activities of this organization are grouped into the categories "Assurance services" and "Advisory services".

Approximately $77 \%$ of the total number of employees are professionals and $23 \%$ are support staff. The case study only focused on the professionals, because they are the employees who must provide valuable solutions to clients based on their knowledge. At "Assurance services" accountants offer services in diverse areas. They audit financial 
information of clients and advise concerning the continuity of these client-organizations. Consultants of "Advisory services" advise clients in various fields like improving business performance and business processes, risk management and information management. In several lines of business both accountants and consultants have to collaborate to deliver customized solutions to clients in these lines that are geared to one another. The line of business investigated in this case study is the "Public Services Sector". The organization structure is shown in a simplified way in Figure 2 below.

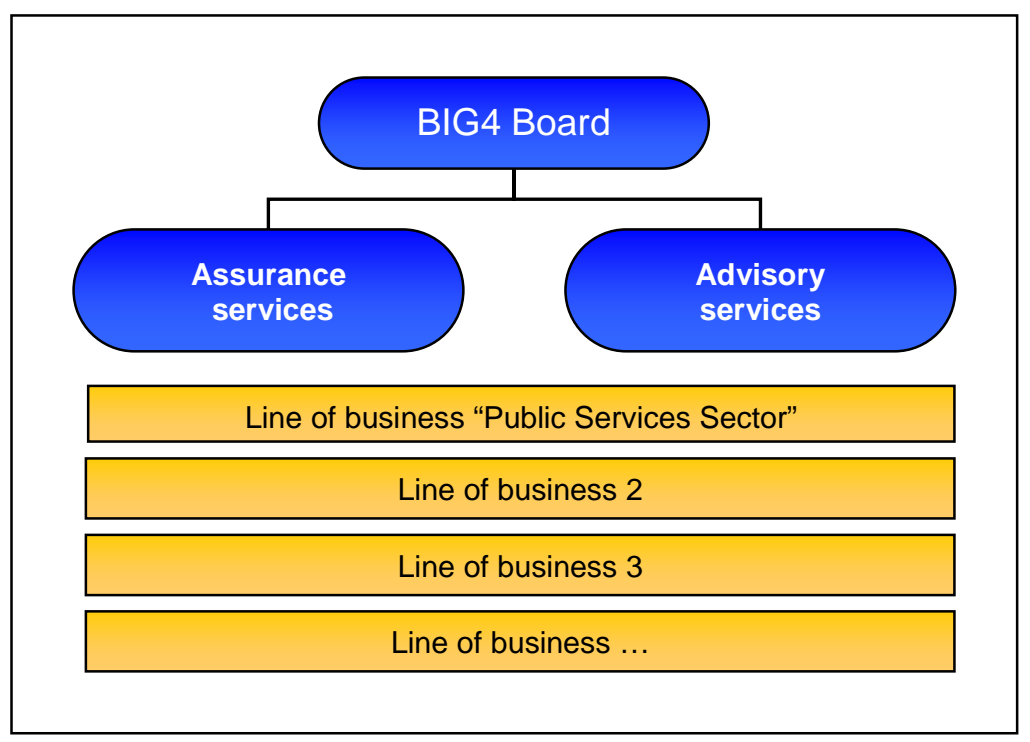

Figure 2: Simplified Organization Chart of BIG4 Netherlands

BIG4 Netherlands is an organization that creates value for its clients based on present knowledge and the skills and intellect of employees. BIG4 creates problem-specific solutions for its clients. These clients expect BIG4 to have good knowledge of their business and organization and they count on advice that fits their specific situations. The knowledge within the organization, both in the form of documents and in the form of employees, is the basis for providing advice that fits to the 'problems' of clients in a certain line of business. This knowledge is the strength and core competence of BIG4. Because BIG4 has specific knowledge in diverse areas and it has taken a strong position in the consulting market. BIG4 is a knowledge intensive organization because it uses the knowledge and skills of its key professionals to provide customized goods and services to its clients.. 
The Dutch BIG4 organization offers possibilities for collaboration. In order to provide correct solutions to clients, the employees are facilitated to cooperate with each other. The management of BIG4 stimulates collaboration between employees. Collaboration between employees has been labeled to this end as one of the core values of the organization. Beside these efforts for collaboration, a myriad of possibilities for using electronic collaborative technologies is available within BIG4 Netherlands. The BIG4 organization has implemented several technologies worldwide and BIG4 Netherlands also offers additional technologies to its employees. These technologies are available for the professionals to support their activities, both individually and in cooperation with colleagues.

\section{Results}

During observations it has been seen that employees of BIG4 Netherlands have access to a wide number of electronic technologies for the support of their daily work. From technologies for searching large amounts of data and information to technologies which support the mutual communication, it is all there. In this section the collaboration technology infrastructure is described, results of the interviews and survey are illustrated. The following sections analyze these results and arrive at an indication for BIG4's Intellectual Bandwidth.

\section{Collaboration Technology Infrastructure}

Through the worldwide Intranet BIG4net a large part of the electronic resources is available. BIG4net is a technology which pops up to employees directly when they connect to the corporate network by starting a browser. All international employees of BIG4 have access to the same internal web pages that provide different functions. BIG4net shows news items and links to external sources like Lexis-Nexis and Goldman Sachs. Also pages with links to Internet sites of the BIG4.com domain, an overview of the worldwide disciplines of BIG4 and information about "what's new" on BIG4net are available. These are pages to browse through information and links to find different sources. Beside these informative pages the employees of BIG4 can also search databases. A 'CV application' for searching and finding persons within BIG4 is available online, where employees can find a résumé based on search terms to make knowledge and experience of employees retraceable for everyone. Moreover there is a search functionality using the technology BIG4Source, a search engine that provides the 
possibility to search information and documents in a database. The following chart illustrates the experience employees have with the collaboration technologies available to them.

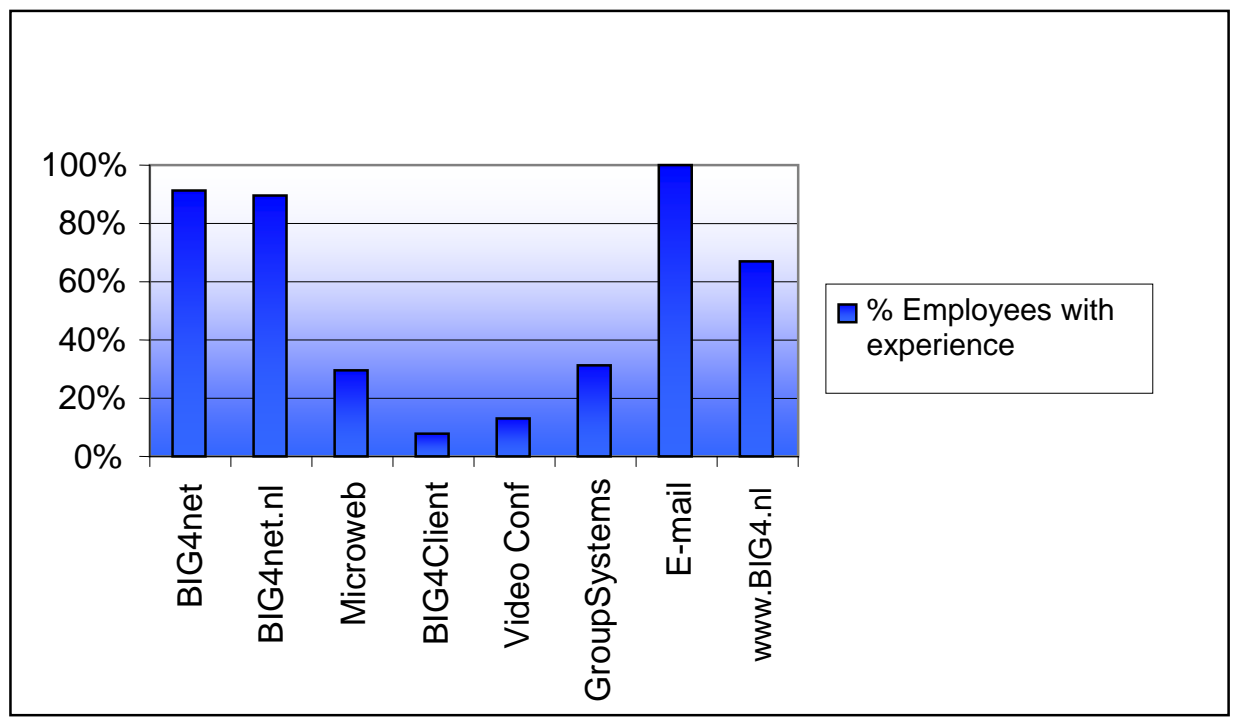

\section{Chart 1: Experience with Collaboration Technologies}

Almost $90 \%$ of the respondents indicated that they had experience with this international part of BIG4net and its national component available for the Dutch BIG4 employees. This national component is called BIG4net.nl and contains pages with information about the Dutch BIG4 organization and employees. Specific newsflashes and descriptions of different Dutch business lines and staff departments are shown. Other pages display an agenda of BIG4 meetings and links to several external sources and an IT helpdesk. BIG4net.nl also presents a bulletin board and another search engine, to search in Dutch databases. Within BIG4net.nl so-called Microwebs exist. These are websites concerning specific units within BIG4 Netherlands, like the Microweb for the unit "Advisory services" or for "market information \& lines of business".

The pages and applications on the intranet with underlying databases represent a large part of all available technologies, but more electronic technologies have been found during the observations. The Dutch Internet site of BIG4, www.BIG4.nl, is also one of the technologies with useful information for employees. BIG4.nl therefore also is a technology which supports the employees in their activities. An alternative technology available for the support of BIG4 employees' activities is called BIG4Client. Hardly $10 \%$ 
of the respondents used this. This technology consists of protected web-based environments where digital work spaces can be created. BIG4Client uses eRoom software and is deployed for the support of distributed collaboration within a BIG4 team and between this team and a client. Using this technology both employees of the client and members of BIG4 teams have the possibility to share documents and to conduct online discussions with each other in a highly secured work space. In the digital work spaces specific expertise of BIG4 is also made available to clients, like BIG4's professional reference.

BIG4 has an agreement with Microsoft as software supplier. Every employee uses the applications of the software Microsoft Office to create documents, presentations and spreadsheets on his personal computer. All the respondents used e-mail. The availability of this technology would almost be considered as obvious given the extent to what the use of e-mail is common in the current society but during observations the possibilities in the field of electronic mail have nevertheless been researched consciously. Employees of BIG4 Netherlands send and receive e-mail using an account on the Microsoft Exchange server. They can also share their mail box with other employees. The account also offers the possibility of maintaining an electronic agenda in which meetings can be scheduled digitally. These electronic agendas can be shared mutually as well, so employees can look at each other's agendas and authorize each other to schedule meetings. Microsoft Exchange server also offers the so-called feature Public Folders. With these folders documents and reports can be made available to several employees at the same time. In an interview one of the information managers told that these Public Folders were created a lot but managed and used poor.

In addition to the technologies described above BIG4 Netherlands offers facilities for the electronic technologies video conferencing and NetMeeting. These technologies make it possible to engage in conversation online while seeing each other on a display device. The tool NetMeeting offers the possibly to share applications on the display device of another and the possibility to chat as well as a shared online whiteboard and the transfer of files. BIG4 has a worldwide NetMeeting directory server available with an address list of all employees who are online. Employees can log in with NetMeeting to have virtual meetings. From a number of observations it became clear that on an average working 
day only about 10 Dutch employees log in. Hardly any respondent on the survey reported the actual use of video conferencing.

During the observations we encountered another technology, a setup for meetings with GroupSystems software. About 30\% of the respondents indicated that they had experience with this technology. There is a fixed setup of computers available with this specific software and a mobile set of computers. The mobile set is employable in a flexible way within the whole organization. Using GroupSystems meetings and brainstorms can be supported. The several components of the GroupSystems software offer the support of group activities such as generating, organizing and evaluating ideas. Also decision making by groups of employees can be simplified using this technology. Although GroupSystems software has the possibility to be used in a distributed form BIG4 Netherlands did not implement this. The employees therefore do not have the possibility of using this software from their personal computer over the network.

\section{Analysis}

The extent to which these technologies provide support for understanding and interdependence is illustrated in this section. The results of the survey and interviews are analyzed using the IB concepts described in section 2. These concepts were assessed using the questionnaire responses and triangulated with open interviews. The results suggest that while the collaborative technology infrastructure appeared to be useful, only a small part of this infrastructure actually supported the use of intellectual resources for the creation of customized goods and services. While the results suggest that work is supported by two very simple technologies, this analysis uncovers the levels of understanding and interdependency at which this work takes place. Following an analysis of the levels of understanding and interdependency that the two most used technologies support, this analysis maps the IB of the line of business investigated at BIG4.

The results illustrate that a majority of the respondents working at the individual level of interdependency, used intranet technology and e-mail to support their daily activities. As shown in chart 1 these are the technologies most of them have experience with. The other technologies mentioned were used by less than $20 \%$ of the respondents for any of 
the activities stated, except the website BIG4.nl for searching information (40,8\%). So if we focus on intranet technology, we find the following Chart 2 :

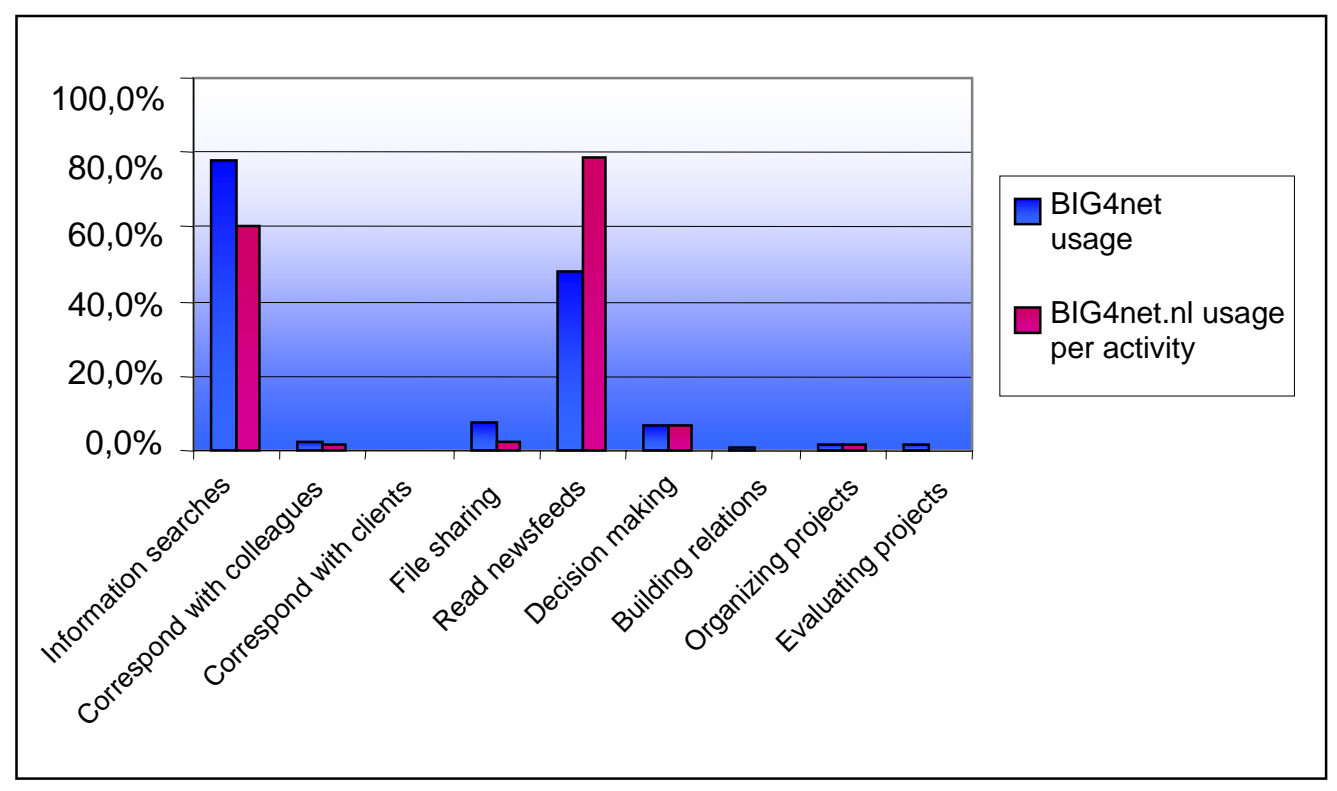

\section{Chart 2: Technology usage: Intranet}

Both the international and national intranet is mainly used for information searches and reading news feeds. Almost $80 \%$ of the respondents use the technology intranet sites to gain understanding by searching information and reading news feeds. The use of e-mail technology to support the activities is shown in the next chart 3 : 


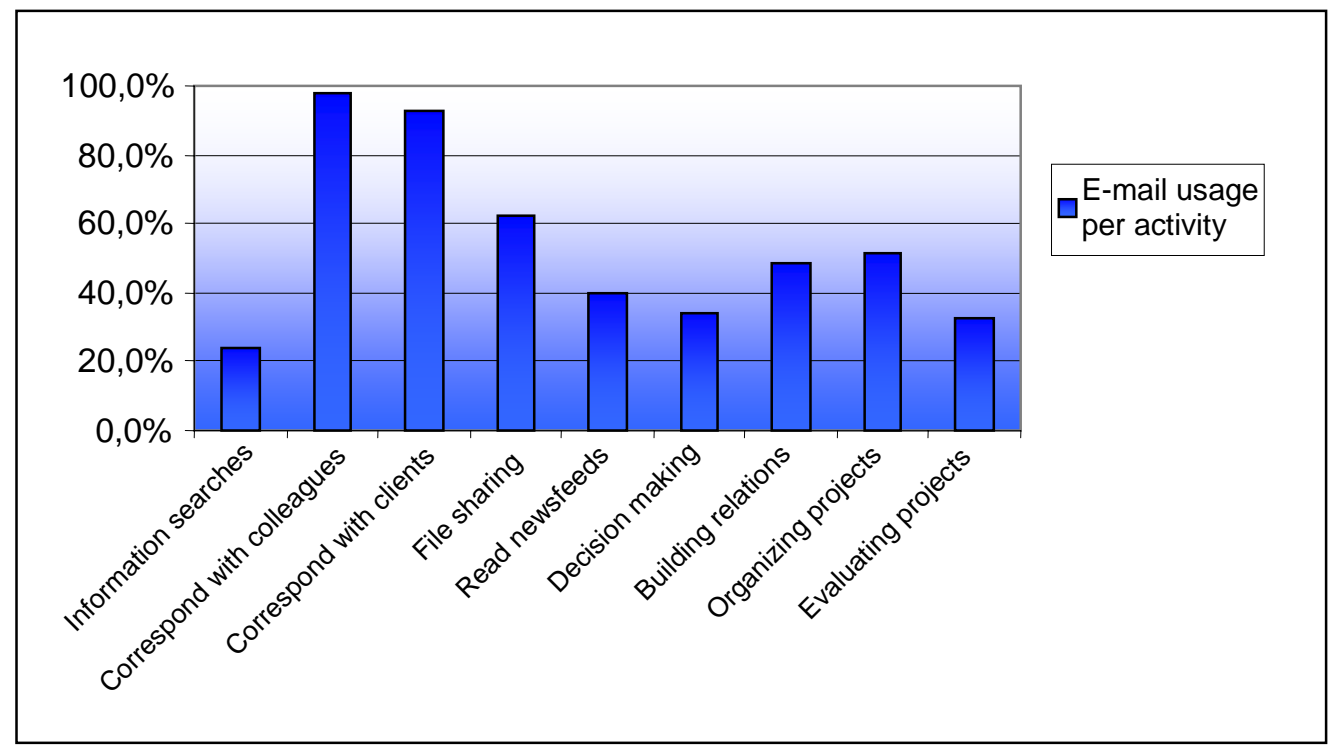

\section{Chart 3: Technology usage: E-mail}

E-mail supports a variety of activities for gaining understanding to a larger extent. Over $90 \%$ of the respondents use e-mail to correspond with colleagues $(97,5 \%)$ and with clients $(92,5 \%)$. Of the respondents who said they work on their own independently of their colleagues, 35\% used the intranets and 55\% used email to support their level of understanding. This is illustrated in the following chart 4 :

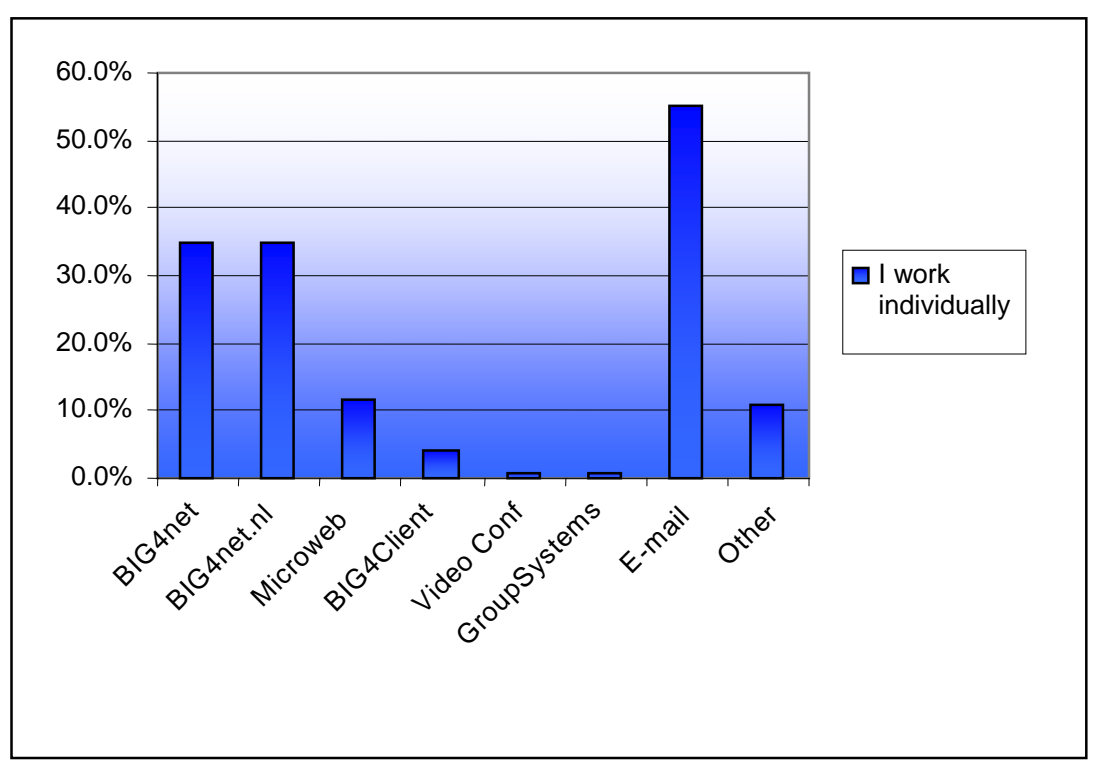

Chart 4: Technologies used for working individually 
It appears from this data that while the members of this organization did depend on each other to carry out their work, their level of interdependency is largely based on individual work. This suggests that both the intranets and email support individual work. When consultants work individually they draw upon data through the intranets which contain specific newsflashes and descriptions of different Dutch business lines and staff departments are shown, search engines and a number of datafeeds from specific databases. They interpret and use this information to carry out their specific tasks. They also use the intranet bulletin board and other document sharing facilities to hand over key work packages at the pre-defined handover deadlines. The extent to which these two technologies were used to support the interdependencies between employees is illustrated in the following chart 5.

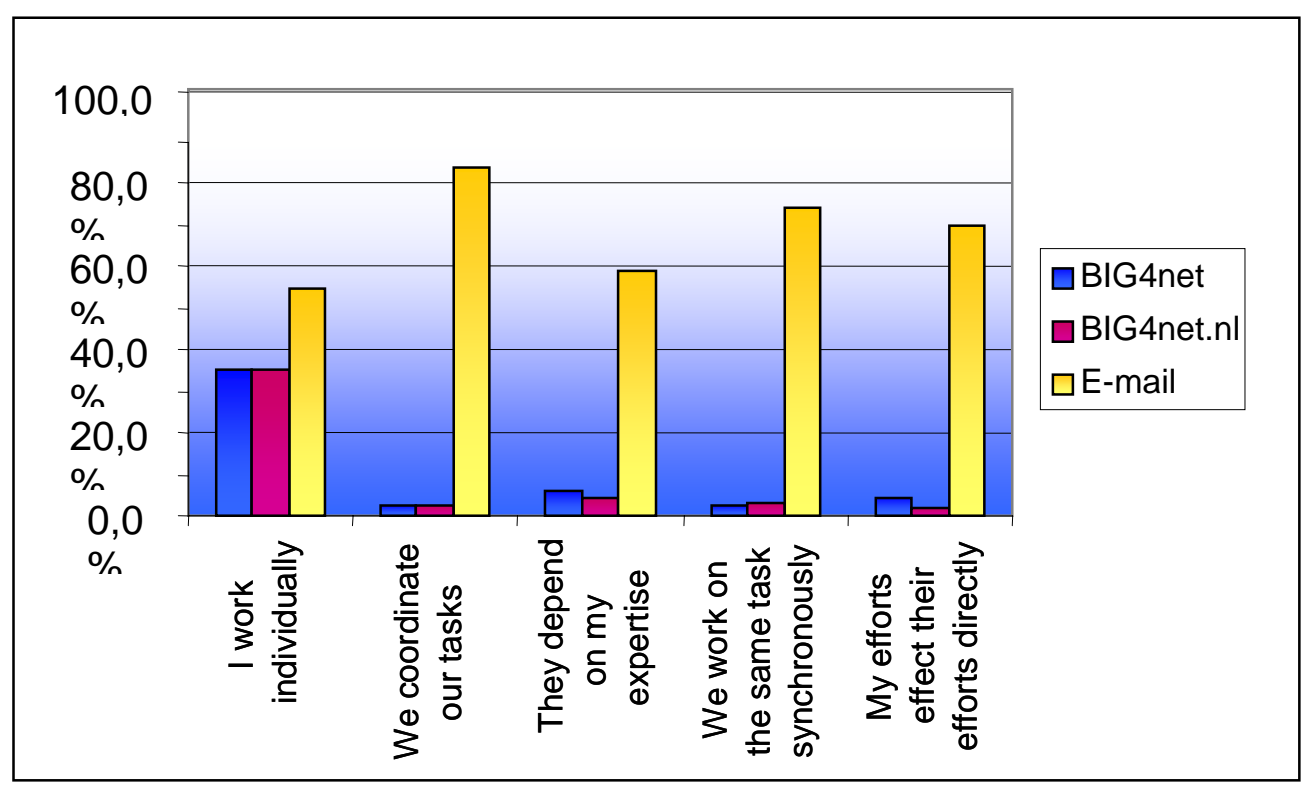

\section{Chart 5: Technologies used for interdependence}

As illustrated in chart 5, the use of the intranets is particularly high at the individual level as it supports understanding at the data level through the use of newsfeeds, interpretation of that data and its use in the context of the projects being carried out. Because there is interpretation of data at the individual level, it appears that the BIG4 consultants use the intranets to work individually at the information level of understanding. At the same time, the respondents used the intranets for the coordination of tasks (2\%), to manage dependencies on expertise (5\%), work synchronously $(2 \%)$ 
and to support each the interdependency of each others' efforts (3\%). This low level of use suggests that the intranets supported the simple sum of multiple interpretations of facts and simple observations. The coordination at the information level of multiple interpretations (coordinated) and more concerted collaboration in which joint deliverables were produced through synchronization of multiple interpretations was supported by email. The IB supported by email and the intranets is illustrated in the following Figure 3.

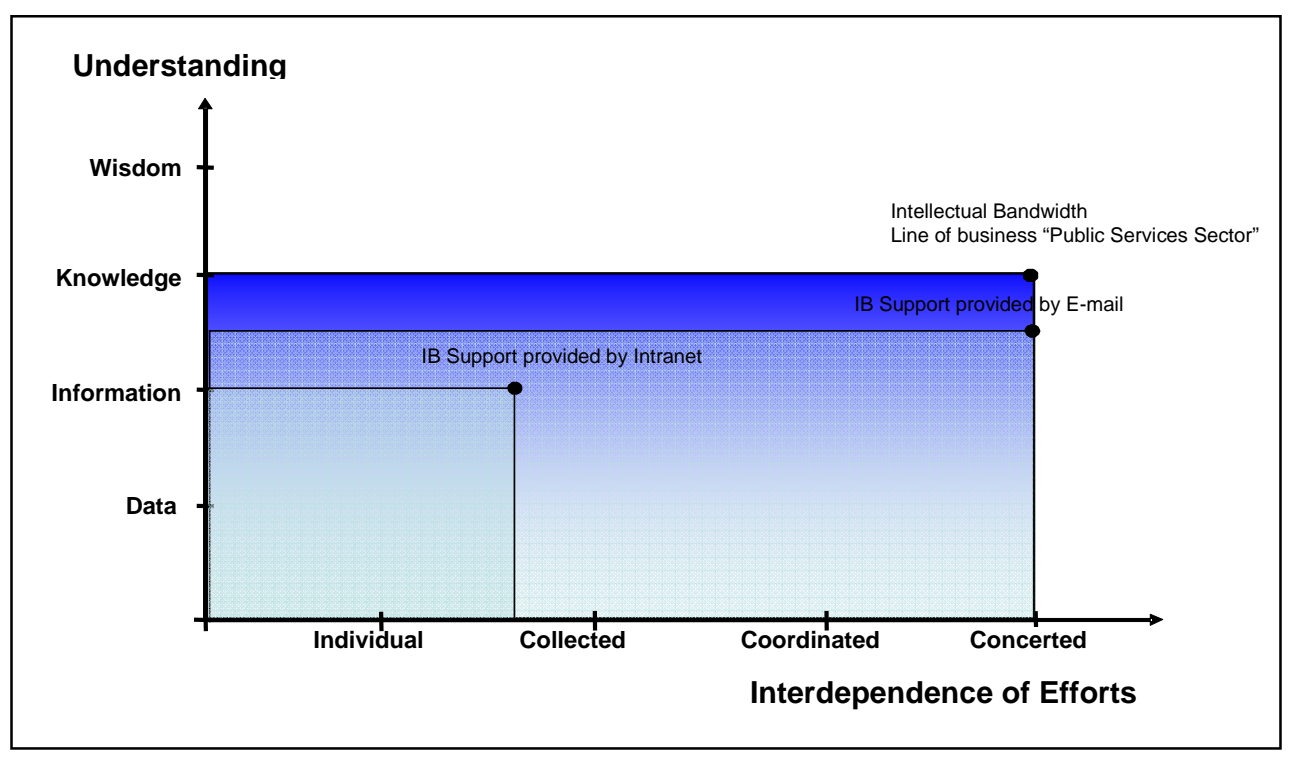

Figure 3: Intellectual Bandwidth of BIG4 NL Line of business "Public Services Sector"

An analysis of the interviews and survey results suggests that the employees of BIG4 who work in the public services sector produce joint deliverables based on the synchronization or creation of shared understanding. They use their understanding of patterns in the context of their emergence (knowledge) in concerted action (concerted). As mapped in figure 3, this is the IB of BIG4's Public Services Sector line of business. The extent to which email supports the IB of this sector is above the information level of understanding as this technology supports the creation of joint deliverables by bringing together multiple interpretations of facts and simple observations as well as the creation of shared understandings. Email does not entirely support the creation of shared understandings of patterns in the context of their emergence as face to face discussions are seen to be more appropriate for this level of interdependency. 


\section{Conclusions and Future Directions}

The intellectual resources of some knowledge intensive organizations are seen to be key to the development of customized goods and services. In order to provide customized goods and services such knowledge intensive organizations rely in the skills and expertise of their employees. Despite the knowledge management efforts and vast investments in information and communication technology (ICT), the use of these intellectual resources remains enigmatic. In view of this challenge, this paper has investigated the extent to which collaborative technologies support the mobilization of intellectual resources to create value for an organization. An investigation has been carried out in a large multinational consulting company, BIG4, using the intellectual bandwidth model to assess the potential of this organization to create value through its intellectual resources. The results suggest that despite the vast collaborative technology infrastructure implemented to support the mobilization of knowledge resources in one of BIG4's line of business, two technologies are used. Of these two, email supports the largest portion of BIG4's IB.

Lessons learned from this research are that the IB of an organization can be supported by the technology that is most easy to use. The greater the complexity of the understanding and interdependency, the simpler the technology used. This has implications for the development of virtual communities in organizations attempting to tap into and mobilize dispersed, personalized intellectual resources. Future research should consider the effect of intranets and virtual collaboration technologies on IB using the instruments developed in this research. In addition, the results of this and other similar research on IB assessments in organizations should inform the implementation of ICT infrastructures in organizations attempting to mobilize their intellectual resources.

\section{References}

Alavi, M. and D. Leidner, Knowledge Management Systems: Emerging Views and Practices from the Field, Proceedings of the $32^{\text {nd }}$ Hawaii International Conference on System Sciences.1999.

Courtney, J. F., Croasdell D. T., and D. B. Paradice, "Inquiring Organizations," Australian Journal of Information Systems, Volume 6, Number 1, pp. 3-15, and Foundations of Information Systems: Towards a Philosophy of Information Technology, http://www.mis.fsu.edu/philosophy/pfis/. September 1998. 
Courtney, J. F. "Decision Making and Knowledge Management in Inquiring Organizations: Toward a New Decision-Making Paradigm for DSS," Decision Support Systems, Vol. 31, No. 1, pp. 17-38. 2001

Davenport, T.H., Information Ecology, Oxford Univ. Press, New York, NY, 1997.

Hansen, M.T., Nohria N., and T. Tierney, "What's your Strategy for Managing Knowledge?" Harvard Business Review. March-April 1999.

Hibbard J. and K.M. Carillo, Knowledge Revolution - Getting employees to share what they know is no longer a technology challenge - it's a corporate culture challenge, InformationWeek, Issue 663, 1998.

Huber, G.P., Organization Leaning: An examination of the Contributing Processes and the Literatures. Organization Science. 2. 88-115. 1991.

Nunamaker, J., Briggs, R.O. and G. J. de Vreede, "From Information Technology to Value Creation Technology". In G. Dickson and G. DeSanctis. Information technology and the New Enterprise: New Models for Managers. Prentice Hall. 2001a.

Nunamaker, J., Briggs, R.O., de Vreede G. J. and R. Sprague. "Special issue: Enhancing Organizations' Intellectual Bandwidth: the Quest for Fast and Effective Value Creation." Journal of Management Information Systems. Vol. 17 no 3: 3-8 2001b.

Nunamaker, J., Romano, N., and R. O. Briggs, "Increasing Intellectual Bandwidth: Generating Value from Intellectual Capital with Information Technology". Group Decision and Negotiation. 2002.

Qureshi, S. and Briggs, B. "Revising the Intellectual Bandwidth Model and Exploring the Use of IB by A Corporate Management Team" In (eds) R. Sprague and J. Nunamaker The Thirty Sixth Annual Hawaii International Conference on Systems Sciences. IEEE Computer Society Press. 2003.

Qureshi, S., van der Vaart, A., Kaulingfreeks, G., de Vreede, G.J., Briggs, R.O. and J. Nunamaker. "What does it Mean for an Organisation to be Intelligent? Measuring Intellectual Bandwidth for Value Creation." The Thirty Fifth Annual Hawaii International Conference on Systems Sciences. IEEE Computer Society Press. 2002.

Quinn, J.B., Intelligent Enterprise. Free Press. New York.1992.

Stein, E. and V. Zwass, "Actualizing Organizational Memory with Information Systems." Information Systems Research. 6(2):85-117, 1995. 
Stewart, T. A. Intellectual Capital: The New Wealth of Organizations. Currency Doubleday. 1997.

Sowell, T, Knowledge and Decision, Basic Books, New York, 1980.

Tallon, P., Kraemer, K. and V. Gurbaxani. "Executives' Perceptions of the Business Value of Information Technology: A Process-Oriented Approach". Journal of Management Information Systems. 16(4): 145-173. 2000.

Tuomi, I. Data is more than knowledge, Journal of Management Information Systems, 16 (3 Winter) 103-117. 2000.

Vance, D. M. Information, Knowledge and Wisdom: The Epistemic Hierarchy and Computer-Based Information System . Proceedings of the 1997 America's Conference on Information Systems.

http://hsb.baylor.edu/ramswoer/ais.ac.97/papers/vance.htm. 1997.

Zack, M., Managing Codified Knowledge. Sloan Management Review. Pp45-58. 1999. 


\section{Publications in the Report Series Research* in Management}

\section{ERIM Research Program: "Business Processes, Logistics and Information Systems"}

\section{4}

Smart Pricing: Linking Pricing Decisions with Operational Insights

Moritz Fleischmann, Joseph M. Hall and David F. Pyke

ERS-2004-001-LIS

http://hdl.handle.net/1765/1114

Mobile operators as banks or vice-versa? and: the challenges of Mobile channels for banks

L-F Pau

ERS-2004-015-LIS

http://hdl.handle.net/1765/1163

Simulation-based solution of stochastic mathematical programs with complementarity constraints: Sample-path analysis S. Ilker Birbil, Gül Gürkan and Ovidiu Listeş ERS-2004-016-LIS

http://hdl.handle.net/1765/1164

Combining economic and social goals in the design of production systems by using ergonomics standards Jan Dul, Henk de Vries, Sandra Verschoof, Wietske Eveleens and Albert Feilzer

ERS-2004-020-LIS

http://hdl.handle.net/1765/1200

Factory Gate Pricing: An Analysis of the Dutch Retail Distribution

H.M. le Blanc, F. Cruijssen, H.A. Fleuren, M.B.M. de Koster

ERS-2004-023-LIS

http://hdl.handle.net/1765/1443

A Review Of Design And Control Of Automated Guided Vehicle Systems

Tuan Le-Anh and M.B.M. De Koster

ERS-2004-030-LIS

http://hdl.handle.net/1765/1323

Online Dispatching Rules For Vehicle-Based Internal Transport Systems

Tuan Le-Anh and M.B.M. De Koster

ERS-2004-031-LIS

http://hdl.handle.net/1765/1324

Generalized Fractional Programming With User Interaction

S.I. Birbil, J.B.G. Frenk and S. Zhang

ERS-2004-033-LIS

http://hdl.handle.net/1765/1325

\footnotetext{
* A complete overview of the ERIM Report Series Research in Management: https://ep.eur.nl/handle/1765/1

ERIM Research Programs:

LIS Business Processes, Logistics and Information Systems

ORG Organizing for Performance

MKT Marketing

F\&A Finance and Accounting

STR Strategy and Entrepreneurship
} 
Meta-heuristics for dynamic lot sizing: A review and comparison of solution approaches

Raf Jans and Zeger Degraeve

ERS-2004-042-LIS

http://hdl.handle.net/1765/1336

Reinventing Crew Scheduling At Netherlands Railways

Erwin Abbink, Matteo Fischetti, Leo Kroon, Gerrit Timmer And Michiel Vromans

ERS-2004-046-LIS

http://hdl.handle.net/1765/1427

Intense Collaboration In Globally Distributed Teams: Evolving Patterns Of Dependencies And Coordination Kuldeep Kumar, Paul C. van Fenema and Mary Ann Von Glinow

ERS-2004-052-LIS

http://hdl.handle.net/1765/1446

The Value Of Information In Reverse Logistics

Michael E. Ketzenberg, Erwin van der Laan and Ruud H. Teunter

ERS-2004-053-LIS

http://hdl.handle.net/1765/1447

Cargo Revenue Management: Bid-Prices For A 0-1 Multi Knapsack Problem

Kevin Pak and Rommert Dekker

ERS-2004-055-LIS

http://hdl.handle.net/1765/1449

Real-Time Scheduling Approaches For Vehicle-Based Internal Transport Systems

Tuan Le-Anh and M.B.M. De Koster

ERS-2004-056-LIS

http://hdl.handle.net/1765/1452

Activating Knowledge Through Electronic Collaboration: Vanquishing The Knowledge Paradox

S. Qureshi and P. Keen

ERS-2004-058-LIS

A Grounded Theory Analysis Of E-Collaboration Effects For Distributed Project Management

S. Qureshi, M. Liu and D. Vogel

ERS-2004-059-LIS

http://hdl.handle.net/1765/1448

Collaborative Infrastructures For Mobilizing Intellectual Resources: Assessing Intellectual Bandwidth In A

Knowledge Intensive Organization

R. Verhoef and S. Qureshi

ERS-2004-060-LIS

Satisfaction Attainment Theory As A Model For Value Creation

R.O. Briggs, S. Qureshi and B. Reining

ERS-2004-062-LIS

http://hdl.handle.net/1765/1450 